\title{
Lincoln's Appointment of United States Justice Samuel F. Miller
}

\author{
By David M. SILVER
}

Abraham Lincoln was to be privileged to appoint five men to the United States Supreme Court, and a Lincoln appointee was to linger on the bench until 1897. Consequently, Lincoln's direct influence upon the court may be said to have endured until that time. . . .

Two main factors controlled the administration's appointments to the court. Lincoln's demand that the selectees have sound views toward the great political issues of the Civil war, and the political forces that guided his selections.

Lincoln did not regard legal training and judicial experience as primary requirements. This was in harmony with his policy of refusing to grant the court the right to provide the final answer on questions that were of political nature. He believed that many men rather than few could meet the requirements for membership on the bench.

An analysis of the previous experience of Lincoln's appointees reveals how little their past activity guided him ... president Lincoln demanded sound views on the war rather than extensive service in the state courts or the lower Federal courts. Lincoln sought men who were trustworthy thinkers on problems of the war and men who were prominent in the profession of the law. But he sought men whose selection would be good politics, as well. And he had to select men who

- Silver, David M., "Lincoln's Supreme Court," Illinois Studies in the Social Sciences, Vol. 38, Chap. IV and V. University of Illinois Press, Urbana, 1956. A thoughtful dissertation of exceptional historical value, from which permission has been granted the ANNaLS to publish excerpts from the copyrighted text relating to President Lincoln's consideration and appointment of Samuel F. Miller of Keokuk, Iowa, as a justice of the United States Supreme Court through nomination made June 16, 1862 , and confirmed the day it was received by the senate. Numbered footnotes refer only to excerpts used herein. 
were geographically available, the circuit system making this demand upon him. It was customary to appoint a man resident in the vacant circuit. This custom, of course, was not observed in selection of a chief justice. . . .

Appointments to the Supreme Court were among those tasks of President Lincoln that did not demand immediate attention. Since the Supreme Court was not in session from March 14, 1861, to December 2, 1861, there was no necessity for presidential action until the later date. But upon the reassembling of the Court in December it was soon demonstrated to the President that he could not long delay naming at least one Justice. As the Congress proceeded to discuss circuit reorganization, it became quite clear to the President that it would be impossible to rely upon early congressional action. The circuit bill was enmeshed in too much political intrigue for that. And soon it became almost obligatory for him to take action.

The urgent situation developed out of the condition of the Court itself. In addition to the three vacancies there were temporary absences resulting from the illness of Chief Justice Taney and Justice Catron. At times it was impossible to maintain in attendance five justices, the number necessary to constitute a quorum. ${ }^{2}$ Lincoln had to make at least one appointment so that the Court could maintain the legal number necessary to function. Furthermore, he began to realize that cases involving the war, particularly the question of the legality of the blockade, would soon reach the Court so it might be well to start to fill the vacancies. ${ }^{3}$

Consequently, President Lincoln nominated Noah Haynes Swayne of Ohio on January 21, 1862. The choice of an Ohioan to replace Justice McLean of the Ohio circuit served to solve the problem of an adequate number of justices to maintain a quorum without dis-

2 New York Tribune, January 23, 1862, p. 5.

3 Ernest Bates, "The Story of the Supreme Court," (Indianapolis, 1936), p. 168. 
turbing the congressional action being taken in relation to the circuit system. . . .

When the senate received the nomination of Swayne, it moved swiftly, confirming the appointment on January 24, 1862. ${ }^{10}$ The new justice arrived in Washington on January 25, took the oath of office in open court on January 27, and assumed his place on the nation's highest tribunal. ${ }^{11}$. . .

Even though Noah Swayne had been elevated to the court, he retained a keen interest in the political intrigue that permeated Washington. Evidence indicates that he was interested in the remaining court vacancies. ... .

\section{Federal Jumicial Circuits Changed}

The revamping of the circuit system became a main consideration of the Thirty-seventh congress despite its preoccupation with problems relative to the war. The president had laid the problem before the legislature to be dealt with as it saw fit. There was to be lengthy delay before congress completed its action, however, as the whole process of reorganization became filled with political considerations. Every congressman realized that filling the court's vacancies depended upon the regrouping of the states into new circuits. Consequently, a congressional battle of great magnitude was fought before reorganization was completed.

For an aspirant to secure one of the vacant seats on the supreme court, victory first had to be won in the congressional fight over the circuits, and politics was given full rein. Ultimately an impatient press strongly condemned the intrigue. But so far as political leaders who were campaigning in behalf of particular candidates were concerned, it was of vital consequence to them to see to it that states with equally prominent aspirants were thrown into different circuits rather than

10 Nomination of Noah H. Swayne, January 21, 1862, Papers of the Attorneys General.

11 Minutes of the United States Supreme Court, January 27, 1862, Clerk's File, Library of the U.S. Supreme Court. 
into the same one-otherwise the possibility of dominating over an appointment was seriously threatened.

The bill to reorganize the circuit system was introduced into the senate on December 9, 1861, by John Sherman of Ohio. Arising out of the recommendations of President Lincoln, the bill was referred to the committee on the judiciary. The process had begun. ...

The circuit system, as it was then constituted, was composed of nine circuits in which the nine members of the Supreme Court held circuit court in conjunction with federal district judges. ${ }^{12}$ Ordinarily a Supreme Court Justice presided over the circuit in which he was a resident. Twenty-five years had elapsed since there was an extensive modification of the circuits, and certain states, including Texas, Florida, Wisconsin, Iowa, Minnesota, Kansas, and the states of the Far West had never been assigned to any circuit. In these states circuit court was presided over by district judges who were granted special power for this purpose or by a special circuit judge.

Senator Trumbull explained that although the bill under consideration did not propose to bring the states of the Far West into a regular circuit system, it was the object of the bill "to equalize the judicial circuits of the United States." The committee, further stated Trumbull, largely basing its action upon the desire to distribute population in the circuits approximately equally, modified the bill introduced by Senator Sherman. . . .

It was in recommendations to condense the Southern and border circuits that the plan of the committee revealed itself. . . .

The committee, in harmony with Republican desires to increase the number of Northern circuits, proposed to assign the three remaining circuits to the Middle West. The proposed middlewestern circuits were: the

12 In the case of Chase MSS. in the Historical Society of Pennsylvania there is a memorandum written by Chase, titled, "Organization and Changes of Circuits," which lists the changes in the circuits from 1789 to 1866 . 
Seventh, Ohio and Kentucky; the Eighth, Wisconsin, Michigan, Indiana, and Minnesota; and the Ninth, Illinois, Missouri, Kansas, and Iowa. The combined total population, $10,219,388$, would compare favorably with the population of the other three Northern circuits and of the three Southern circuits. Senator Trumbull stated that the three vacancies on the Supreme Court would be filled from the Middle West and the new Justices would be assigned to these circuits. . . .

At this time Senator James W. Grimes of Iowa proposed several alterations in the bill. Grimes sought a Supreme Court appointment for his friend Samuel F. Miller, a Republican leader in Iowa, and if Iowa were in a circuit with Illinois, Miller would have to compete with such Supreme Court apsirants as David Davis and Orville $H$. Browning. Grimes believed that the placing of Iowa in a circuit with Illinois would be fatal to Miller's chances and consequently worked diligently to bring about some change.

\section{The New Ninth Circuit}

He proposed that the Ninth Circuit be composed of Missouri, Iowa, Kansas, and Minnesota; in addition, he suggested other changes, the most important of which were that Ohio and Michigan should be placed together and that Illinois be grouped with Indiana and Wisconsin. Grimes admitted that his proposed Ninth Circuit would be small in population but it was "rapidly increasing," and he explained that the states he grouped in it had a simplified legal code in common. Grimes shrewdly reassigned Ohio, hoping that this would bring him the support of Ohio's senators.

The Senate was not impressed with Grimes's proposals and rejected them, finally accepting the proposals of the Trumbull committee. The senatorial snarl on the circuits was broken. But the battle was to rage on, the scene shifting to the House of Representatives.

Members of the House also had begun, after hearing the President's message, to consider reorganization of the circuits. . . . 
Those forces that were lobbying for favorites now turned their big guns on the House of Representatives. The intensity of the struggle increased, and the rivalries threatened to prevent the passage of any reorganization bill whatsoever.

A leading actor in the struggle in the House was James F. Wilson of Iowa, whose recent appointment to the committee on the judiciary was to prove highly advantageous to the cause of Samuel F. Miller. Wilson waged a skillful battle to place Iowa in a circuit in which Miller would not encounter competition with other leading aspirants. Under the leadership of Representative Wilson the bill that the Senate referred to the House was bottled up in the committee on the judiciary during the months of February, March, April, and May, 1862.

During the months of delay, those interested in forcing action to place Iowa in a circuit with Missouri, Minnesota, and Kansas sought through every legislative strategem to win their objective. The legislature of Iowa, itself, passed a resolution on March 10, 1862, urging Iowa's congressional delegation to battle for a suitable circuit, ${ }^{16}$ and finally it even petitioned Congress to grant its wishes. ${ }^{17}$

At last on June 4 the reorganization bill was reported to the House. The committee on the judiciary recommended significant changes: the Seventh Circuit would consist of Ohio, Kentucky, and Michigan; the Eighth, Indiana, Illinois, and Wisconsin; and the Ninth, Missouri, Iowa, Kansas, and Minnesota. ${ }^{18}$

Representative Wilson explained that it was proper that a circuit should be formed consisting of certain trans-Mississippi states, and it was as a consequence that he urged setting up a circuit composed of Mis-

16 Sen. Misc. Doc. No. 73, 37th Cong., 2nd sess., p. 1.

17 Petition to Congress, referred to the Senate committee on the judiciary on March 26, 1862, Thirty-Seventh Congress, United States Senate Files, National Archives.

18 The ensuing debate in the House of Representatives is to be found in the Cong. Globe, 37th Cong., 2nd sess., pp. 2561-65. 
souri, Iowa, Kansas, and Minnesota. Arguing the need for such a circuit, Wilson declared that no other part of the nation was growing so rapidly. He said that the states he wished to join with Iowa had similar legal codes and that the commerce and trade of these four states were connected with the Mississippi and Missouri rivers.

John F. Potter of Wisconsin rose promptly to challenge Wilson's assignment of Wisconsin. Wilson countered that the change regarding Wisconsin simply made for a more compact and symmetrical circuit! This circuit-juggling provoked Representative Kellogg to make a keen analysis, declaring: "I fear that too many mantles for Supreme Court judges have already been cut out, and made up. If it were not for that, there would be little trouble in arranging the States in compact circuits." ...

As adjournment of Congress loomed, the reorganization bill finally gained momentum, and the House moved rapidly toward passage of the bill. Representative John W. Menzies of Kentucky and Representative Horace Maynard of Tennessee succeeded in having Kentucky placed in the same circuit as Tennessee. Following this decision, the House accepted the bill, amended to meet the desires of Representative Wilson. The Iowans had accomplished in the House what they had failed to accomplish in the Senate. Each branch of Congress had its own plan; it remained to be seen which would bow to the wishes of the other.

\section{THE IMPASSE BROKEN}

With Senate and House at odds, even the keenest political forecasters were unable to predict what the final action would be. . . .

The Senate was ready to make its decision and accepted the House bill except that it adopted the request of Senator Wright and joined Indiana with Ohio and Michigan, and assigned to Kentucky Indiana's former position with Illinois and Wisconsin. The Senate had acceded very largely to the wishes of the House. The 
efforts of Senator Grimes and Representative Wilson were successful. Their dilatory tactics had brought victory. All that remained was to obtain final approval by the House.

A few days later, however, Representative Wilson moved that the House insist fully upon the terms of its bill, and he asked that a conference be held with the Senate. Senators Jacob Collamer of Vermont, Joseph A. Wright of Indiana, and John C. Ten Eyck of New Jersey represented the Senate in the resulting conference. Representatives John A. Bingham of Ohio. James F. Wilson of Iowa, and Robert Mallory of Kentucky represented the House.

Following meetings of the conference committee in which a number of readjustments were made in the circuit assignments, the House of Representatives accepted the committee's recommendations. Circuit reorganization was nearing enactment into law. . : .

Before the final vote on the conference report the Senate rejected an effort by Senator Henry M. Rice of Minnesota to postpone action until the following December. Then the Senate accepted the conference report. The circuit reorganization bill was passed. Lincoln's signature completed enactment on July 15, 1862. ... the new Ninth included Missouri, Iowa, Kansas, and Minnesota.

The main battle, that involving the creation of a trans-Mississippi judicial circuit, was won by Representative James F. Wilson and Senator James W. Grimes. They delayed and jeopardized circuit reorganization, but they succeeded in their demands. Their next step was to influence President Lincoln to select their favorite for appointment to the Supreme Court. That would crown their efforts with the fullest measure of success. . . .

\section{A Seat Marked}

Lincoln's second appointee to the Supreme Court, Samuel Freeman Miller, received a medical degree in 1838 and practiced medicine in Kentucky for more 
than a decade. From the time of his college days, however, he had a keen interest in politics. This interest led him to study law surreptitiously, while practicing medicine, and he was admitted to the bar in 1847. Miller, as were most of his neighbors, was a Whig party member. Although he was born in Kentucky in 1816, he opposed slavery and looked forward to the day when his state, through a process of gradual emancipation, would be free.

When Kentucky retained the institution of slavery in its constitution of 1849 , Miller determined to establish himself and his family elsewhere. He settled in Keokuk, Iowa, formed the law firm of Reeves and Miller, and became active in the Republican party. In 1861 he was a candidate for the Republican nomination for governor of Iowa, and at the time of his appointment by Lincoln he was chairman of the Republican district committee at Keokuk.

Two factors governed the choice of Miller for appointment to the Supreme Court: creation of a transMississippi circuit which included Iowa and development of overwhelming pressures in his behalf. Miller's cohorts in the Congress fought the battle of circuit reorganization with both skill and resourcefulness. And Miller's friends at home flooded the President with a deluge of recommendations, even though at the time Miller was practically unknown outside his adopted state.

\section{SUPPORTED MILLER's SELECTION}

Recommendations came to Lincoln's desk in behalf of Miller from the governor of Iowa, the United States senators from Iowa, the United States representatives from Iowa, the Iowa state bar, the Iowa state legislature, the attorney general of Iowa, the Iowa state supreme court judges, and a multitude of others. Miller's friends, who even saw to it that petitions from "Iowa State Citizens" were added to the pile, left no stone unturned.

The recommendations that poured in upon Lincoln 
appealed to every motive that could influence him. Bypassing the trite, it is interesting to examine some of the most original. Lincoln was asked to select Miller as a compliment to Iowa "whose devotion to our Union is so . . . deserving." 32 Francis Springer, former judge of the first judicial district of Iowa, was certain that he expressed "the opinion of the Bar and Bench" when he declared that "as a jurist (albeit Miller had no experience as a judge) he has no superior in the State." 32 The Iowa attorney general recommended Miller as an "earnest Patriot and conscientious Republican," and added that he "has never held a public office."34

The President was told that the "loyal, thinking people of Iowa would be gratified" by Miller's appointment. $^{35}$ Judge George C. Wright of the Iowa supreme court wrote, "In the full prime and vigor of healthy manhood ... devoted to his country at all times and all the more in this hour of her greatest peril, I deem him in every way qualified." 36 And this was not all that came to the President's desk in behalf of Samuel Miller.

Meant for the President's eyes, too, was a letter from J. C. Hall, former judge of the Iowa supreme court, which said that if the circuits were reorganized "Iowa of course will expect Some appointment upon the Bench."37 Edward Johnstone, who told the President that he had opposed Miller politically, wrote to endorse him for the Supreme Court, remarking, "The Citizens of the Upper Mississippi Valley believe that this region . . . is entitled to be represented on the Federal Bench."38 MSS.

32 Daniel F. Miller to Abraham Lincoln, December 10, 1861, Lincoln

33 Francis Springer to Abraham Lincoln, December 11, 1861, ibid.

34 C. C. Nourse to Abraham Lincoln, December 14, 1861, ibid.

- 35 Caleb Baldwin to Abraham Lincoln, December 16, 1861, ibid.

36 George C. Wright to Abraham Lincoln, December 16, 1861, ibid.

37 J. C. Hall to James W. Grimes, December 16, 1861, ibid.

38 Edward Johnstone to Abraham Lincoln, December 30, 1861, ibid. 
And yet the letters came. At the end of the letter that was lavish with praise for Miller, Judge James M. Love of the Federal district court for Iowa said, "I beg leave to add that in what I have just said I have spoken not the language of mere empty compliment and inconsiderate commendation." 39 Amusingly, Joseph C. Knappe wrote to Lincoln urging the appointment, saying that Miller "has had an extensive practice in the United States District Court for ... Iowa, in which Court, for Eight years-and until removed by your Excellency-I discharged the duties of United States Attorney .... Mr. Miller and myself-as you will of course infer-differ politically. . . ."40

\section{KasSON SAW LinCOLN}

Interviews that two champions of Miller had with Lincoln throw considerable light upon the appointment. John A. Kasson of Des Moines, whom Lincoln had appointed first assistant postmaster general and who later was elected to Congress, was requested by Miller to call upon Lincoln and intervene in his behalf. Kasson learned that Miller's reputation had not extended as far as Springfield and that the President had Miller confused with Daniel F. Miller who had represented Iowa in the Thirty-First Congress (1849-1851). $\mathrm{He}$ proceeded to correct the . President's misunderstanding and to sketch for him the career and qualifications of Samuel F. Miller. ${ }^{41}$

The other interview with Lincoln was held by Governor Samuel J. Kirkwood of Iowa, Senator James Harlan, and several members of the Iowa delegation to the House of Representatives. Senator Harlan explained that they had come in regard "to that appointment." And the Governor remarked that the appointment would be "a very fit and proper one to be made." But no one, as yet, had mentioned the office or the name of

39 J. M. Love to Abraham Lincoln, January 1, 1862, ibid.

40 Joseph C. Knappe to Abraham Lincoln, January 4, 1862, ibid.

41 John A. Kasson to Charles Aldrich, November 10, 1893, quoted in ANNALs of IowA, January 1894, I, 252. 
the man who was to be appointed. This gave the President an opportunity to poke a little fun at his visitors. Kirkwood had found Lincoln obliging in the past, especially in relation to military appointments. Lincoln "picked up his pen, and drawing a paper to him as if to make the appointment in compliance with their wishes, said to them, "what is the office and whom do you wish to be placed in it?" "

The Iowans were almost overcome. Senator Harlan quickly stated their request: "We wish to have Mr. Miller of Iowa chosen by you to the vacancy on the Supreme Bench." Lincoln, who was well aware of their hopes, replied. " 'Well, well,' . . . replacing the pen and pushing back his paper, 'that is a very important position and I will have to give it serious consideration. I had supposed you wanted me to make some one a Brigadier General for you.' " Lincoln had his little joke at the expense of the Iowans, but with the interview at an end they had no assurance that their request would be granted. ${ }^{42}$

Lincoln acceded to their wishes the day after he signed the circuit reorganization bill. On July 16, 1862, President Lincoln nominated Samuel F. Miller to the Supreme Court. The nomination was "read, considered, and confirmed" the day it was received by the Senate. Iowa's politicians had tasted the fruits of their talents twice within two days. They got their trans-Mississippi circuit, and they got the appointment for Samuel Miller, too.

\section{Confused With ANother Miller}

The newspapers reacted in a confused manner to this appointment. Some of them were unable to decide whether the new Justice was Samuel F. Miller or Daniel F. Miller. The confusion is significant evidence of the obscurity of the new appointee. Some newspapers apparently knew or could learn so little about Miller that they could carry only a statement

$42 \mathrm{H}$. W. Lathrop, "Judge Miller's Appointment to the Supreme Court," Iowa Historical Record, January, 1891, VII, 17. 
that the appointment was made. ${ }^{43}$ The New York Tribune went so far as to correct the dispatches, saying, "Mr. Miller's name is printed Samuel in the dispatches, but we presume it is Daniel F. Miller, the first Whig member of Congress ever chosen from Iowa." "44 In discussing the appointment in an editorial titled "New Supreme Judge," the Chicago Tribune, however, properly identified Miller as a Republican leader of Iowa and referred to him correctly as Samuel F. Miller. ${ }^{45}$

The confusion in the East did not clear up quickly. Months after the appointment was made the Washington Morning Chronicle quoted comments from the New York Post which discussed Daniel F. Miller as a member of the United States Supreme Court. The Chronicle, referring to the new justice as a "sterling patriot," said, "A blunder similar to the above was recently made by the same journal which lashed itself into a fierce rage over its own exclusive announcement that the late Secretary of the Interior (Caleb B. Smith) had been placed upon the Supreme Bench. Is ignorance of the personnel of the Supreme Court a specialty of the Post?" 46

\section{Receives His Commission}

Justice Miller received his commission from Attorney General Bates on July 19 and was administered the oath of office by chief Justice Taney on July 21. When Taney administered the oath, he saw standing in front of him a man of striking appearance, "large, well built, with massive head, clear-cut features, and a pair of bright, penetrating eyes." $47 \mathrm{He}$ was a man who made friends easily, delighted in good compan-

${ }^{43}$ Washington Daily Globe, July 17, 1862, p. 4; Washington Evening Star, July 17, 1862, p. 2; Baltimore Sun, July 17, 1862, p. 2; New York Times, July 17, 1862, p. 5; New York World, July 17, 1862, p. 1; New York Herald, July 17, 1862, p. 1; Chicago Tribune, July 18, 1862, p. 1 .

44 New York Tribune, July 18, 1862, p. 4.

${ }^{45}$ Editorial, Chicago Tribune, July 21, 1862, p. 2.

46 Editorial, Washington Morning Chronicle, January 24, 1862, p. 2.

47 Horace Stern, "Samuel Freeman Miller," Great American Lawyers (Philadelphia, 1909), VI, 548-49. 
ionship, excelled as a conversationalist, and had a good sense of humor.

Previously, Miller had held no public office. Of course it was not by deliberate design that Lincoln chose a man without previous public experience, but it is highly significant that lack of public service did not prevent Lincoln from naming him. Despite the critical statement that Miller's preponderant qualification was that he was chairman of the Republican district committee at Keokuk,"48 selection of Miller was not out of harmony with Lincoln's concept of what qualified a man for elevation to the Supreme Court.

In the Robert Todd Lincoln collection there are few communications sent by Justice Miller to the President, but two of them reveal Miller's relation to the administration. In one Miller recommended to Lincoln appointment of Caleb Baldwin of Council Bluffs, Iowa, to be a director of the Union Pacific railroad. ${ }^{49}$ The other was a telegram in which Miller called Lincoln's attention to a case of arbitrary arrest. Here, again, one of Lincoln's Supreme Court appointees interested himself in arbitrary arrest. In a telegram from St. Louis, Miller told Lincoln that J. G. Turner of Richmond, Kentucky, had been arrested and sent to Memphis. "I know nothing of the facts (telegraphed Miller) and have satisfactory assurances that Judge Breck \& Curtis T. Burnham of whose devoted loyalty there can be no doubt \& who are his neighbors say that he is wrongfully arrested(.)" Miller added that the prisoner was over seventy years of age and asked Lincoln to modify the order so as to send Turner to Washington, Indiana, where he had a son. In conclusion Miller

48 Ewing, "The Judges of the Supreme Court," p. 105. A leading student of Miller's career, Charles N. Gregory, states that Miller, fully aware of his limited legal preparation, proceeded in the early days of his service on the Supreme Court to study every reported case heard by the Court from its first term to the time he took his seat. Charles N. Gregory, "Samuel Freeman Miller, Associate Justice of the Supreme Court of the United States," Yale Law Journal, April, 1908, XVII, 428.

40 Samuel F. Miller to Abraham Lincoln, September 26, 1863, Lincoln MSS. 
said he believed that in this way "all useful purposes may be subserved without cruelty(.) This I Earnestly beg may be done(.)"50

\section{Miller Previously Little Known}

In an address before the Iowa State Bar Association a Des Moines in 1879 Justice Miller admitted how little known he was when he was elevated to the bench. He attributed his appointment to the heartiness and "unanimity with which the bar of my own State recommended" it. He declared that he had always been gratified that Democrats of the Iowa bar joined Republicans to back his candidacy. ${ }^{51}$

At a later date Justice Miller wrote Mrs. James W. Grimes, widow of the Senator, a lengthy letter explaining the story of his appointment and the role that Senator Grimes played in obtaining it. He said that it was known that his appointment depended upon establishment of a trans-Mississippi circuit and that Senator Grimes, Senator Harlan, and Representative Wilson all fought for its creation. He added that Grimes secured the signatures of twenty-eight senators on a petition urging the appointment. And Representative Wilson, whose assistance "was especially efficient," circulated a similar petition in the House which was signed by one hundred and twenty members. ${ }^{52}$

Miller, whose legal training left so much to be desired, was a self-made jurist with little systematic approach to the law. His strength on the bench rested in the capacity he had to think independently and logically. Although he came to the bench with strong

50 Samuel F. Miller to Abraham Lincoln, October 8, 1864, ibid.

51 Address of Mr. Justice Miller Delivered Before the Iowa State Bar Association at Des Moines, May 13, 1879, quoted in Albany Law Journal, July $12,1879, \mathrm{XX}, 25$.

52 Samuel F. Miller to Mrs. James W. Grimes, August 28, 1888, Iowa Historical Record, April, 1891, VII, 88-89. Miller stated that these petitions were presented to Lincoln but admitted that at a later date the President declared ". . . in my presence that no such recommendations for office had ever been made to him." Ibid. 
antislavery bias and could well have been immoderate, he practiced self-restraint as a justice. ${ }^{53}$

Justice Miller proved to be "second to none" in the difficult task that the Supreme Court faced during the Civil War-the task of seeing that "no just power of the General Government should be lost, and on the other (hand), no just right of a State or of a citizen should be sacrificed."54 Although Miller had the task of overcoming inadequate training and lack of experience in governmental responsibilities, this liability was so well surmounted that he finally was to rank with a halfdozen other Supreme Court Justices "who, after Marshall, have impressed their personalities upon our constitutional law."

53 Fairman, "Mr. Justice Miller and the Supreme Court," p. 67.

54137 U.S. 704-05. .

55 Charles Fairman, ed., "Justice Samuel F. Miller and the Barbourville Debating Society," Missisippi Valley Historical Review, March, 1931, XVII, 595.

\section{When I Grow Old}

\section{By Fredda Schaefer}

When I grow old, will people say

That I have helped along the way?

Will they be able to recall

My friendliness to one and all,

To unknown stranger, next-door neighbor,

Without a thought of gaining favor?

Will children small remember me

As one they visited with glee?

Will my sons grown tall and strong,

Accept the right, reject the wrong?

Have I taught them the golden rule

Of living-truths not learned at school?

By my example have I shown

That with the years I too have grown,

That values true I can assess?

Then treasure rare I shall possess-

Not costly jewel by money bought,

But sweet content by service wrought. 
Copyright of Annals of Iowa is the property of State of Iowa, by \& through the State Historical Society of Iowa and its content may not be copied or emailed to multiple sites or posted to a listserv without the copyright holder's express written permission. However, users may print, download, or email articles for individual use. 